\title{
Towards a chemical mechanism of the oxidation of aqueous sulfur dioxide via isoprene hydroxyl hydroperoxides (ISOPOOH)
}

\author{
Eleni Dovrou $^{1, \mathrm{a}}$, Kelvin H. Bates ${ }^{2}$, Jean C. Rivera-Rios ${ }^{3, \mathrm{~b}}$, Joshua L. Cox ${ }^{3}$, Joshua D. Shutter ${ }^{3}$, and \\ Frank N. Keutsch ${ }^{1,3,4}$ \\ ${ }^{1}$ John A. Paulson School of Engineering and Applied Sciences, Harvard University, Cambridge, MA 02138, USA \\ ${ }^{2}$ Harvard University Center for the Environment, Cambridge, MA 02138, USA \\ ${ }^{3}$ Department of Chemistry and Chemical Biology, Harvard University, Cambridge, MA 02138, USA \\ ${ }^{4}$ Department of Earth and Planetary Sciences, Harvard University, Cambridge, MA 02138, USA \\ ${ }^{a}$ now at: Multiphase Chemistry Department, Max Planck Institute for Chemistry, 55128 Mainz, Germany \\ bnow at: School of Chemical \& Biomolecular Engineering, Georgia Institute of Technology, Atlanta, GA 30332, USA
}

Correspondence: Eleni Dovrou (dovrouel@gmail.com) and Frank Keutsch (keutsch@seas.harvard.edu)

Received: 26 February 2021 - Discussion started: 8 March 2021

Revised: 4 May 2021 - Accepted: 18 May 2021 - Published: 14 June 2021

\begin{abstract}
In-cloud chemistry has important ramifications for atmospheric particulate matter formation and gas-phase chemistry. Recent work has shown that, like hydrogen peroxide $\left(\mathrm{H}_{2} \mathrm{O}_{2}\right)$, the two main isomers of isoprene hydroxyl hydroperoxide (ISOPOOH) oxidize sulfur dioxide dissolved in cloud droplets $\left(\mathrm{SO}_{2, \mathrm{aq}}\right)$ to sulfate. The work revealed that the pathway of $\mathrm{SO}_{2}$,aq oxidation with ISOPOOH differs from that of $\mathrm{H}_{2} \mathrm{O}_{2}$. We investigate the chemical mechanisms of oxidation of $\mathrm{SO}_{2}$,aq with ISOPOOH in the cloudrelevant $\mathrm{pH}$ range of 3-6 and compare them with the previously reported mechanisms of oxidation of $\mathrm{SO}_{2 \text {,aq }}$ with $\mathrm{H}_{2} \mathrm{O}_{2}$, methyl hydroperoxide and peroxyacetic acid. The organic products of the reaction are identified, and two pathways are proposed. For 1,2-ISOPOOH, a higher yield pathway via proposed radical intermediates yields methyl vinyl ketone (MVK) and formaldehyde, which can react to hydroxymethanesulfonate (HMS) when $\mathrm{SO}_{2 \text {,aq }}$ is present. A lower yield non-fragmentation oxygen addition pathway is proposed that results in the formation of isoprene-derived diols (ISOPOH). Based on global simulations, this mechanism is not a significant pathway for formation of MVK and formaldehyde relative to their gas-phase formation but, as previously reported, it can be regionally important for sulfate production. The study adds to previous work that highlights similarities and differences between gas-phase and clouddroplet processing of reactive organic carbon.
\end{abstract}

\section{Introduction}

Isoprene $\left(\mathrm{C}_{5} \mathrm{H}_{8}\right)$ is the main non-methane biogenic volatile organic compound emitted to the atmosphere with global emission estimates of $\sim 470 \mathrm{TgC}$ (Guenther et al., 2006, 2012; St. Clair et al., 2016). In the atmosphere, $\mathrm{C}_{5} \mathrm{H}_{8}$ primarily reacts with hydroxyl radicals $(\mathrm{OH})$ forming peroxy radicals $\left(\mathrm{RO}_{2}\right)$ after oxygen addition (Wennberg et al., 2018). Under pristine, $\mathrm{HO}_{2}$-dominated (low-NO) conditions, isoprene $\mathrm{RO}_{2}$ reacts with hydroperoxyl radicals $\left(\mathrm{HO}_{2}\right)$ to form multifunctional organic hydroperoxides, isoprene hydroxyl hydroperoxides (ISOPOOH, $\mathrm{C}_{5} \mathrm{H}_{10} \mathrm{O}_{3}$ ), of which 1hydroxyl-2-hydroperoxyl- and 4-hydroxyl-3-hydroperoxylISOPOOH (1,2-ISOPOOH and 4,3-ISOPOOH, respectively) are the most abundant isomers (Rivera-Rios et al., 2014; Krechmer et al., 2015; St. Clair et al., 2016). ISOPOOH mixing ratios of up to $1 \mathrm{ppb}$ and up to $\sim 2 \mathrm{ppb}$ have been reported in the Amazon rainforest and the Blodgett Forest Research Station in California, respectively (Worton et al., 2013; Liu et al., 2016).

In the gas phase, ISOPOOH is oxidized by $\mathrm{OH}$ to primarily produce isoprene epoxydiols (IEPOX), which contribute to secondary organic aerosol (SOA) mass (Paulot et al., 2009a; Surratt et al., 2010; Lin et al., 2012; Nguyen et al., 2014; McNeill, 2015; Zhang et al., 2018). St Clair et al. (2016) investigated the gas-phase oxidation mechanism of ISOPOOH and elucidated some non-IEPOX oxidation path- 
Table 1. Sulfate production rate constants and yields in the aqueous phase due to oxidation of $\mathrm{SO}_{2 \text {, aq }}$ via 1,2-ISOPOOH and 4,3ISOPOOH (Dovrou et al., 2019b).

\begin{tabular}{|c|c|c|c|c|}
\hline & \multicolumn{2}{|c|}{$1,2-\mathrm{ISOPOOH}+\mathrm{HSO}_{3}^{-}$} & \multicolumn{2}{|c|}{$4,3-\mathrm{ISOPOOH}+\mathrm{HSO}_{3}^{-}$} \\
\hline & $\begin{array}{l}\text { Rate constant } \\
\left(\mathrm{M}^{-1} \mathrm{~s}^{-1}\right)\end{array}$ & $\begin{array}{r}\text { Sulfate } \\
\text { yield } \\
(\%)\end{array}$ & $\begin{array}{l}\text { Rate constant } \\
\left(\mathrm{M}^{-1} \mathrm{~s}^{-1}\right)\end{array}$ & $\begin{array}{r}\text { Sulfate } \\
\text { yield } \\
(\%)\end{array}$ \\
\hline $\mathrm{pH}=5.5$ & $1.65( \pm 0.28) \times 10^{3}$ & 67 & $1.80( \pm 0.23) \times 10^{2}$ & 83 \\
\hline $\mathrm{pH}=4.5$ & $1.00( \pm 0.28) \times 10^{3}$ & 100 & $1.90( \pm 0.18) \times 10^{2}$ & 100 \\
\hline $\mathrm{pH}=3$ & $1.00( \pm 0.42) \times 10^{3}$ & 100 & $2.90( \pm 0.30) \times 10^{2}$ & 100 \\
\hline
\end{tabular}

ways, and Krechmer et al. (2015) observed the formation of non-IEPOX low volatile organic compounds that contribute to SOA. These pathways are summarized and compiled into a complete gas phase mechanism in the work of Wennberg et al. (2018).

Having Henry's law constants on the order of $10^{5} \mathrm{Matm}^{-1}$, ISOPOOH isomers can partition into cloud and fog water and participate in condensed-phase reactions (Rivera-Rios, 2018). Dovrou et al. (2019b) showed that ISOPOOH oxidizes sulfur dioxide $\left(\mathrm{SO}_{2, \mathrm{aq}}\right)$ in cloud and fog water, producing sulfate $\left(\mathrm{SO}_{4}^{2-}\right) . \mathrm{SO}_{2, \text { aq }}$ reacts with water to form sulfurous acid $\left(\mathrm{SO}_{2} \cdot \mathrm{H}_{2} \mathrm{O}\right)$, which dissociates to bisulfite $\left(\mathrm{HSO}_{3}^{-}\right)$when $\mathrm{pH}>2$. At higher $\mathrm{pH}(\mathrm{pH}>6)$, $\mathrm{HSO}_{3}^{-}$subsequently dissociates to form sulfite $\left(\mathrm{SO}_{3}^{2-}\right)$. In cloud $\mathrm{pH}$ range of 3-6 the dominant form of $\mathrm{SO}_{2 \text {,aq }}$ is $\mathrm{HSO}_{3}^{-}$, and our study investigated $\mathrm{pH}$ values of $3,4.5$ and 5.5 (Fig. S1 in the Supplement). Aqueous hydrogen peroxide $\left(\mathrm{H}_{2} \mathrm{O}_{2}\right)$ oxidizes $\mathrm{SO}_{2 \text {,aq }}$ to sulfate with a $100 \%$ yield with a rate constant that increases with decreasing $\mathrm{pH}$ (Lind et al., 1987). Dovrou et al. (2019b) reported that at $\mathrm{pH}=5.5$ the rate constant for oxidation of $\mathrm{SO}_{2}$, aq by 1,2 -ISOPOOH is equal, within uncertainty, to that of oxidation of $\mathrm{SO}_{2, \text { aq }}$ by $\mathrm{H}_{2} \mathrm{O}_{2}$ at $\mathrm{pH}=5.5$, while the rate constant of the oxidation for $\mathrm{SO}_{2}$, aq by 4,3-ISOPOOH is an order of magnitude lower. The rate constants for the reactions of both ISOPOOH isomers with $\mathrm{SO}_{2}$,aq have a much smaller $\mathrm{pH}$ dependence than that of $\mathrm{H}_{2} \mathrm{O}_{2}+\mathrm{SO}_{2}$,aq. Similar to $\mathrm{H}_{2} \mathrm{O}_{2}$, the sulfate yield at $\mathrm{pH}=4.5$ and 3 is $100 \%$ for both ISOPOOH isomers. However, Dovrou et al. (2019b) showed that for $\mathrm{pH}=5.5$ the sulfate yield is only $67 \%$ and $83 \%$ of the reacted $\mathrm{SO}_{2 \text {,aq }}$ for 1,2-ISOPOOH and 4,3-ISOPOOH, respectively (Table 1). Due to its higher abundance, solubility and rate of reaction with $\mathrm{SO}_{2, \mathrm{aq}}, 1,2$-ISOPOOH contributes much more to atmospheric sulfate production than the 4,3 isomer (Dovrou et al., 2019b).

The differences between both the sulfate yield and the $\mathrm{pH}-$ dependence of rate constants suggest that the chemical mechanisms of $\mathrm{SO}_{2}$,aq oxidation via $\mathrm{H}_{2} \mathrm{O}_{2}$ and ISOPOOH are different. Hoffmann and Edwards (1975) proposed a mechanism for the oxidation of $\mathrm{HSO}_{3}^{-}$by $\mathrm{H}_{2} \mathrm{O}_{2}$ :

$$
\begin{aligned}
& \mathrm{H}_{2} \mathrm{O}_{2}+\mathrm{HSO}_{3}^{-} \leftrightharpoons \mathrm{HOOSO}_{2}^{-}+\mathrm{H}_{2} \mathrm{O} \\
& \mathrm{HOOSO}_{2}^{-}+\mathrm{H}^{+} \rightarrow \mathrm{HSO}_{4}^{-}+\mathrm{H}^{+},
\end{aligned}
$$

with Reaction (R2), rearrangement of peroxysulfite, being the rate-limiting step. To compare by $\mathrm{H}_{2} \mathrm{O}_{2}$ and understand the mechanism of $\mathrm{SO}_{2}$,aq oxidation with ISOPOOH, timedependent proton nuclear resonance $\left({ }^{1} \mathrm{H}-\mathrm{NMR}\right)$ spectra of the reaction were obtained.

\section{Materials and methods}

\subsection{Chemical and sample preparation}

Sodium metabisulfite was purchased from Sigma Aldrich (purity $\geq 99 \%$ ) and used as the source of bisulfite $\left(\mathrm{HSO}_{3}^{-}\right)$ in the solutions (Dovrou et al., 2019b). Formaldehyde solution ( $37 \mathrm{wt}$ \% in $\mathrm{H}_{2} \mathrm{O}, 10 \%-15 \%$ methanol as stabilizer), methyl vinyl ketone (MVK, purity 99\%), formaldehydesodium bisulfite adduct (hydroxymethanesulfonate, HMS, purity $95 \%$ ), acetic acid (purity $\geq 99.7 \%$ ), dimethyl sulfoxide (DMSO, purity $\geq 99.7 \%$ ), 2-methyl-2-vinyloxirane (purity 95\%) and 3-(trimethylsilyl)-1-propanesulfonic acid sodium salt (purity 97\%) were purchased from Sigma Aldrich. The two main ISOPOOH isomers, 1,2-ISOPOOH and 4,3-ISOPOOH, were synthesized in the lab according to the procedures described by Rivera-Rios (2018). Hydrogen peroxide $\left(\mathrm{H}_{2} \mathrm{O}_{2}\right)$ was purchased from Sigma Aldrich (30 wt. \% in $\mathrm{H}_{2} \mathrm{O}$ ), and filtered Milli-Q water and deuterium oxide $\left(\mathrm{D}_{2} \mathrm{O}\right)$ were used as solvents.

2-Methyl-3-butene-1,2-diol (1,2-ISOPOH) was synthesized, following the procedure in Zhang et al. (2012) and Bates et al. (2014), by hydrolysing 2-methyl-2-vinyloxirane. Approximately $5400 \mathrm{mg}$ of 2-methyl-2-vinyloxirane was dissolved in $54 \mathrm{~mL}$ of $0.1 \mathrm{M} \mathrm{HCl}$ at $50^{\circ} \mathrm{C}$ for $30 \mathrm{~min}$. The procedure was modified by saturating the reaction mixture with sodium chloride $(\mathrm{NaCl})$, instead of lyophilizing it. Subsequently, the diol was isolated via extraction with diethyl ether. The diethyl ether solution was then evaporated under reduced pressure to isolate the diol. The purity of the diol was determined to be $70 \%$ using NMR analysis, and the identified impurities were diethyl ether, water, and the 1,2ISOPOH dimer.

Samples for kinetics experiments were prepared with a ratio of $\frac{\left[\mathrm{HSO}_{3}^{-}\right]}{\text {[hydroperoxide] }}=\frac{2}{1}$ and $\frac{\left[\mathrm{HSO}_{3}^{-}\right]}{[\mathrm{MVK}]}=\frac{2}{1}$, as discussed in Dovrou et al. (2019b). The concentrations of the ion chromatography (IC) and NMR spectrometry experiments were $10 \mathrm{~s}$ of $\mu \mathrm{M}$ and a few $\mathrm{mM}$, respectively, based on the sensitivity of the methods. For the NMR analysis of standards, $1 \mathrm{mM}$ concentrations were used. After completion of reactions, $0.1-2 \mathrm{mM}$ standards were added to identify proposed products by observing increases in the intensity of the corresponding peaks in the spectra. 
Table 2. Carbon budget of the 1,2-ISOPOOH$+\mathrm{SO}_{2}$, aq reaction and molar yields. Carbon concentrations are in mM. Hydrated formaldehyde could not be quantified as it is under the large $\mathrm{D}_{2} \mathrm{O}$ signal. At lower $\mathrm{pH}$, acetic acid may be lost to the gas phase.

\begin{tabular}{lrrr|rrr}
\hline & \multicolumn{3}{c|}{ Carbon concentration } & \multicolumn{3}{c}{ Molar yield } \\
\cline { 2 - 6 } & $\mathrm{pH}=5.5$ & $\mathrm{pH}=4.5$ & $\mathrm{pH}=3$ & $\mathrm{pH}=5.5$ & $\mathrm{pH}=4.5$ & $\mathrm{pH}=3$ \\
\hline 1,2-ISOPOOH & 5 & 5 & 5 & & & \\
HMS & 0.3 & 0.2 & 0.2 & $30( \pm 4) \%$ & $20( \pm 3) \%$ & $20( \pm 5) \%$ \\
MVK & 1.2 & 0.8 & 0.9 & $30( \pm 6) \%$ & $20( \pm 4) \%$ & $23( \pm 4) \%$ \\
1,2-ISOPOH & 1.1 & 0.7 & 0.8 & $22( \pm 4) \%$ & $14( \pm 2) \%$ & $16( \pm 6) \%$ \\
Acetic acid & 0.1 & 0.01 & 0.02 & $5( \pm 1) \%$ & $0.5( \pm 0.03) \%$ & $1( \pm 0.08) \%$ \\
Sum & 2.7 & 1.7 & 1.9 & $57 \%$ & $35 \%$ & $40 \%$ \\
\hline
\end{tabular}

\subsection{Ion chromatography and NMR analysis}

A Dionex ICS-5000+ IC system and an Agilent I500B NMR were used to analyse the samples and quantify sulfate produced. The AG12A guard column and the AS12A analytical column (Dionex Ionpac) were selected in order to separate sulfur-containing species (Dovrou et al., 2019a). The mobile phase was $4.5 \mathrm{mM}: 1.4 \mathrm{mM}$ sodium carbonate/sodium bicarbonate with a flow rate of $1.5 \mathrm{~mL} \mathrm{~min}^{-1}$ (Dovrou et al., 2019b). ${ }^{1} \mathrm{H}-\mathrm{NMR}$ was used to identify the organic reaction products. For the conducted experiments, 16 and 32 scan averages were chosen, with a relaxation delay of $45 \mathrm{~s}$ and at proton operating frequency of $400 \mathrm{MHz}$.

All experiments were repeated at least 4 times, each sample was prepared separately prior to analysis, and temperature and $\mathrm{pH}$ were monitored. DMSO, methanol and 3-(trimethylsilyl)-1-propanesulfonic acid sodium salt $\left(\left(\mathrm{CH}_{3}\right)_{3} \mathrm{Si}\left(\mathrm{CH}_{2}\right)_{3} \mathrm{SO}_{3} \mathrm{Na}\right)$ were used as internal standards for quantitative yields.

\section{Results and discussion}

\subsection{Product identification}

Figure 1 shows the NMR spectra of 1,2- and 4,3-ISOPOOH standards in $\mathrm{D}_{2} \mathrm{O}$ (broad peak at $4.7 \mathrm{ppm}$ ) together with the NMR spectra after reaction of ISOPOOH with a two-fold excess of $\mathrm{SO}_{2}$,aq at three different $\mathrm{pH}$ values. After completion of the $\mathrm{SO}_{2, \mathrm{aq}}+\mathrm{ISOPOOH}$ reaction at $\mathrm{pH}=5.5$ the ISOPOOH precursors are not observable and a number of high-intensity ${ }^{1} \mathrm{H}-\mathrm{NMR}$ signals are observed. Signals with the same shifts are observed under more acidic conditions but with slightly lower intensity, while some of the smaller peaks from the $\mathrm{pH}=5.5$ spectra of both isomers are not observed in the $\mathrm{pH}=4.5$ and 3 spectra. This is consistent with the hypothesis that the reaction and product distribution have a pH dependence and suggests competition between different reaction paths. These different paths may also explain the $\mathrm{pH}$ dependence of the observed sulfate yields.

Products were identified via comparison of ${ }^{1} \mathrm{H}-\mathrm{NMR}$ spectra of standards as well as spiking $\mathrm{SO}_{2, \text { aq }}+\mathrm{ISOPOOH}$ mix- tures after completion of reaction with standards of the proposed products. Methyl vinyl ketone (MVK), methacrolein (MACR) and (hydrated) formaldehyde ( $\mathrm{HCHO}$ ), all major products of gas-phase oxidation, were identified by their ${ }^{1}$ H-NMR chemical shifts (St. Clair et al., 2016). Due to its higher importance, the 1,2-ISOPOOH reaction and products were examined in more detail. For this reaction at $\mathrm{pH}=5.5 \mathrm{MVK}$ ( $30 \%$ molar yield), hydrated formaldehyde $\left(\mathrm{CH}_{2}(\mathrm{OH})_{2}\right)$, HMS (30\% molar yield), 1,2-ISOPOH $(22 \%$ molar yield) and acetic acid (5\% molar yield) were the main products (Fig. 2a and Table 2). The products of the $\mathrm{SO}_{2, \text { aq }}+4,3$-ISOPOOH reaction included $\mathrm{CH}_{2}(\mathrm{OH})_{2}, 4,3$ ISOPOH and HMS (Fig. 2b). In both reactions, $\mathrm{CH}_{2}(\mathrm{OH})_{2}$ is under the large $\mathrm{D}_{2} \mathrm{O}$ peak, $\delta \approx 4.74 \mathrm{ppm}$, which prevents quantification (Sect. 3.2). 2-Methyl-2-vinyloxirane was also used as a standard, but it was not observed as a product (Fig. S2 in the Supplement). The standard spectrum showed that 2-methyl-2-vinyloxirane hydrolyzed to 1,2-ISOPOH under the experimental conditions, although not very rapidly. Thus, we cannot exclude that 2-methyl-2-vinyloxirane is formed and rapidly hydrolyzed to 1,2-ISOPOH, although the timescale of the experiments should have allowed its observation. Some minor product signals could not be identified; for example, a signal in the $\mathrm{SO}_{2, \text { aq }}+1,2-\mathrm{ISOPOOH}$ $\mathrm{pH}=5.5$ spectrum at $\delta=1.43 \mathrm{ppm}$ (Fig. 1) is likely a methyl group not adjacent to a carbonyl group based on its chemical shift; however, we were not able to identify the corresponding compound.

\subsection{Proposed reaction pathways}

It is instructive to consider the previously studied oxidation of $\mathrm{SO}_{2}$,aq with $\mathrm{H}_{2} \mathrm{O}_{2}$ (Reactions R1-R2) and methyl hydroperoxide $\left(\mathrm{CH}_{3} \mathrm{OOH}\right.$; Reaction $\left.\mathrm{R} 3\right)$, and to lesser degree peroxyacetic acid $\left(\mathrm{CH}_{3} \mathrm{C}(\mathrm{O}) \mathrm{OOH}\right.$; Reaction $\left.\mathrm{R} 4\right)$ (Lind et al., 1987).

$$
\begin{aligned}
\mathrm{HOSO}_{2}^{-} & +\mathrm{CH}_{3} \mathrm{OOH} \rightarrow 0.73\left(\mathrm{SO}_{4}^{2-}+\mathrm{H}^{+}+\mathrm{CH}_{3} \mathrm{OH}\right) \\
& +0.27\left(\mathrm{CH}_{3} \mathrm{OSO}_{3}^{-}+\mathrm{H}_{2} \mathrm{O}\right)
\end{aligned}
$$


(a)

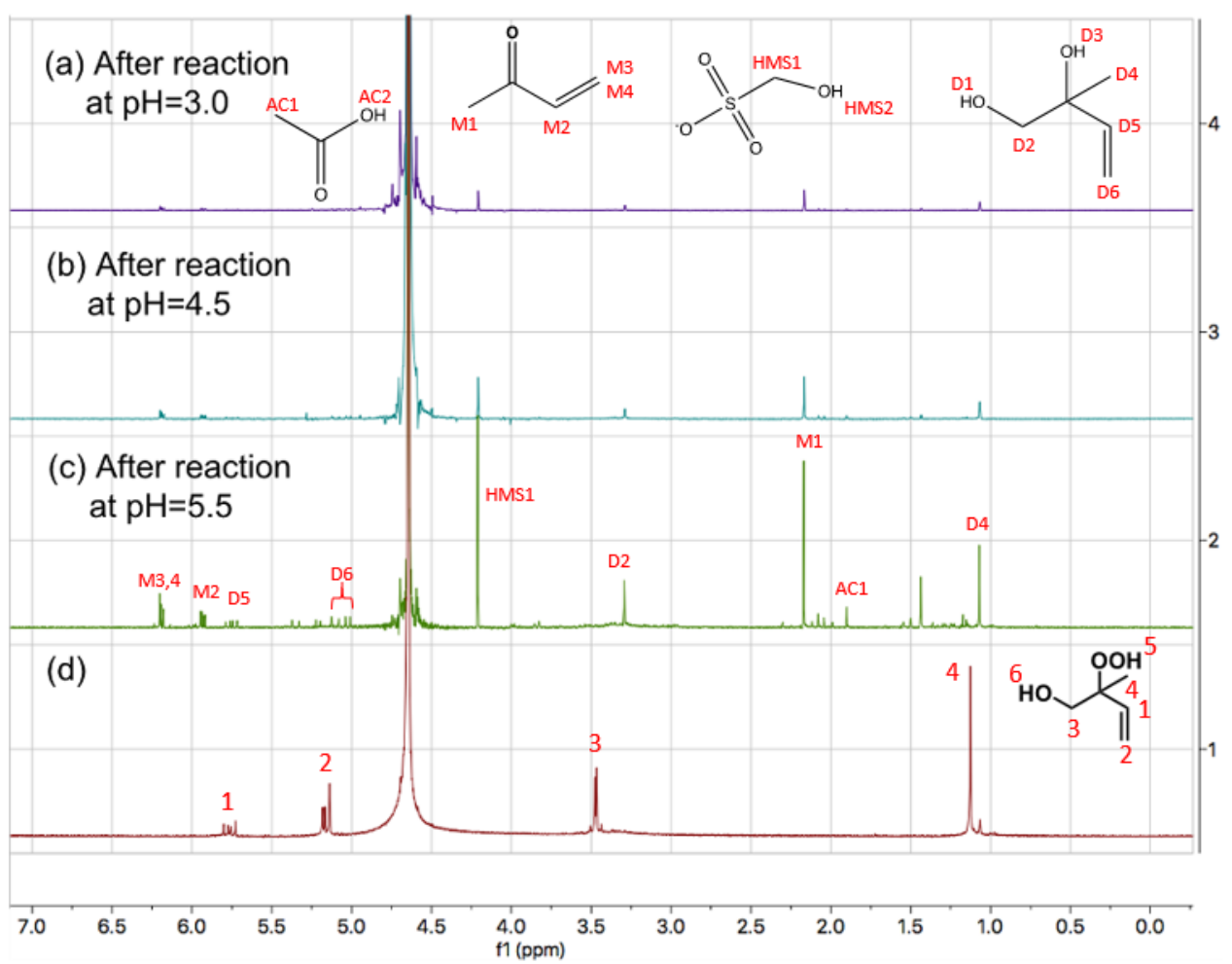

(b)

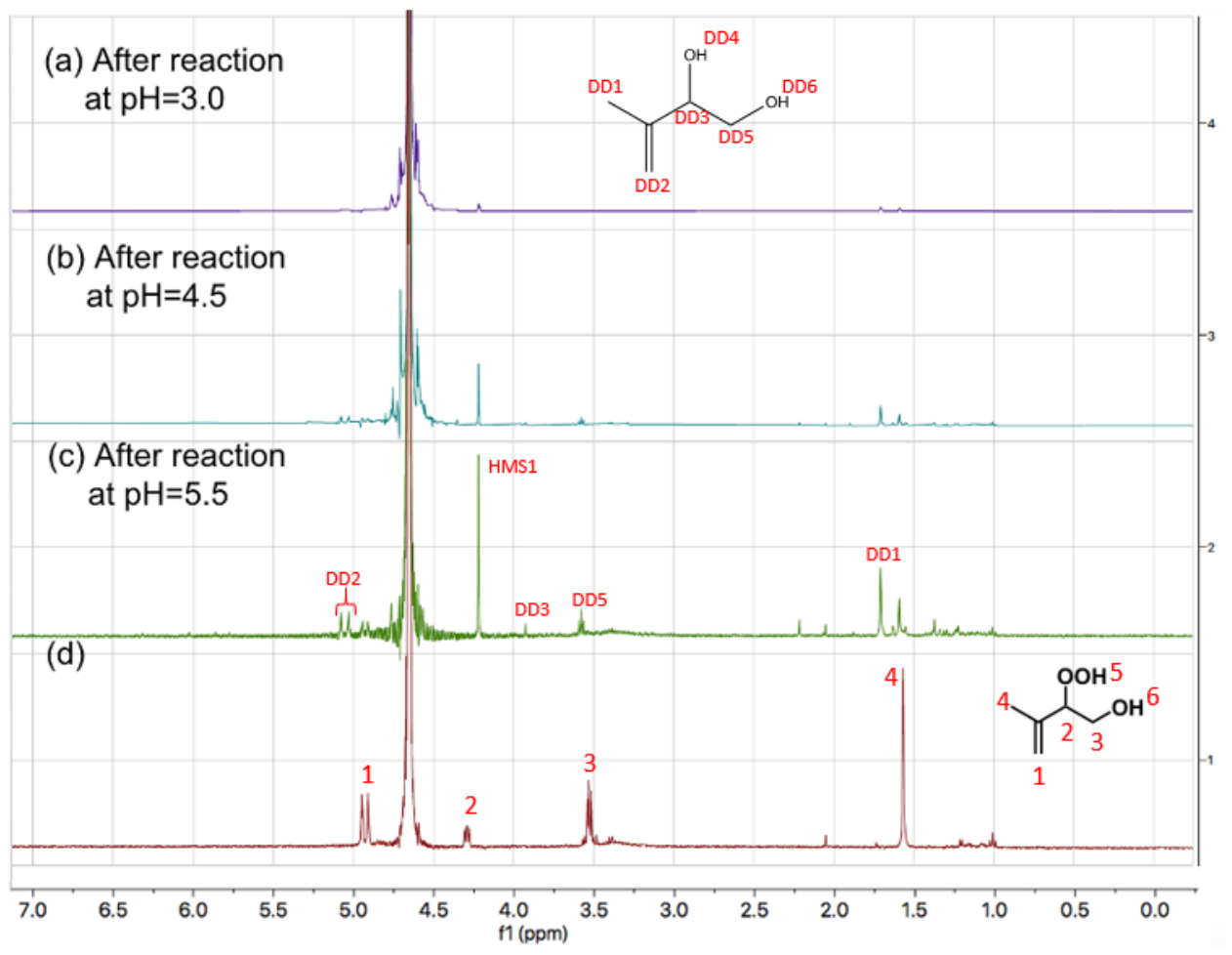

Figure 1. Proton NMR spectra $\left({ }^{1} \mathrm{H}-\mathrm{NMR}, 400 \mathrm{MHz}, \mathrm{D}_{2} \mathrm{O}\right)$ of (A) 1,2-ISOPOOH (d) and the products of the reaction of $\mathrm{SO}_{2, \mathrm{aq}}+1,2-$ ISOPOOH at (a) $\mathrm{pH}=3,(\mathbf{b}) \mathrm{pH}=4.5$ and (c) $\mathrm{pH}=5.5$ and (B) 4,3-ISOPOOH (d) and the products of the reactions of $\mathrm{SO}_{2, \text { aq }}+4,3-$ ISOPOOH at (a) $\mathrm{pH}=3$, (b) $\mathrm{pH}=4.5$ and (c) $\mathrm{pH}=5.5$. The concentration of the ISOPOOH isomers was $1 \mathrm{mM}$, and the concentration of $\mathrm{SO}_{2, \text { aq }}$ was $2 \mathrm{mM}$. The spectra are focused on the areas of change. Chemical structures of (a,d) 1,2-ISOPOOH and (b,d) 4,3-ISOPOOH are presented. The labels at each peak represent the hydrogens of the compounds and the spectra are shifted for $\mathrm{D}_{2} \mathrm{O}$ at $4.67 \mathrm{ppm}$. 
(a)

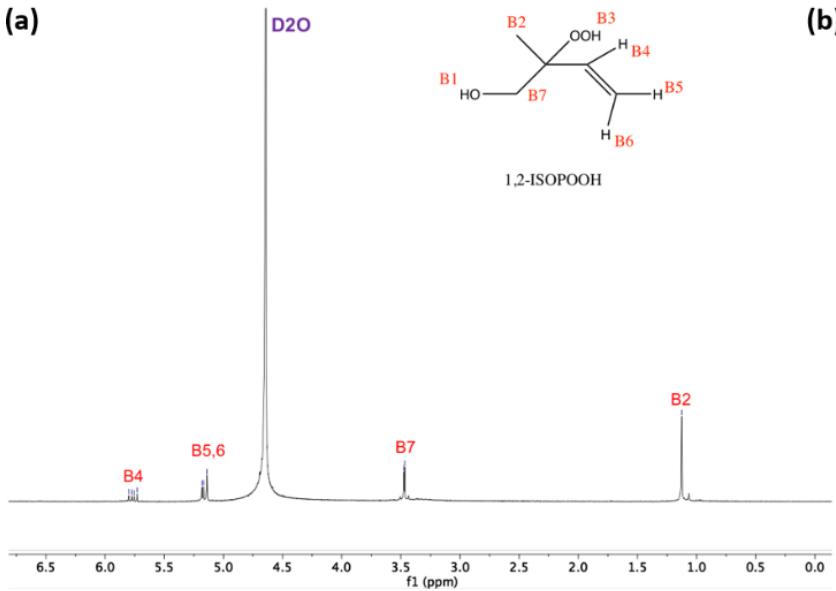

(b)

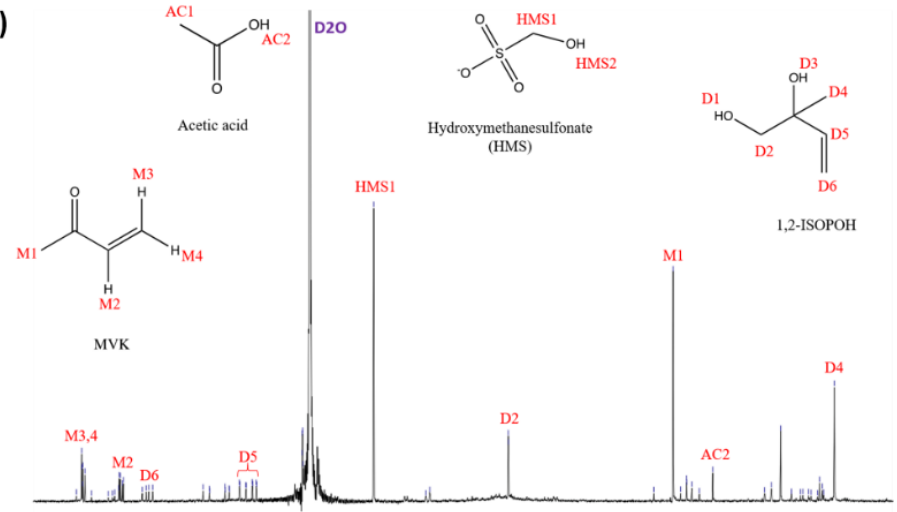

Figure 2. Proton NMR spectra $\left({ }^{1} \mathrm{H}-\mathrm{NMR}, 400 \mathrm{MHz}, \mathrm{D}_{2} \mathrm{O}\right)$ for $1,2-\mathrm{ISOPOOH}(\mathbf{a})$, and products of the reaction of $\mathrm{SO}_{2}$, aq $+1,2$ ISOPOOH (b). The marked peaks represent the position of the hydrogens for each molecule. The $\mathrm{pH}$ of the samples was 5.5 and the concentrations used were $[1,2-\mathrm{ISOPOOH}]=1 \mathrm{mM}$ and $\left[\mathrm{SO}_{2, \mathrm{aq}}\right]=2 \mathrm{mM}$. $\mathrm{D}_{2} \mathrm{O}$ shift at $4.67 \mathrm{ppm}$.

$$
\begin{aligned}
\mathrm{HOSO}_{2}^{-} & +\mathrm{CH}_{3} \mathrm{C}(\mathrm{O}) \mathrm{OOH} \rightarrow \mathrm{SO}_{4}^{2-}+\mathrm{H}^{+} \\
& +\mathrm{CH}_{3} \mathrm{COOH}
\end{aligned}
$$

Reaction (3) has two pathways oxidizing S(IV) to S(VI): a higher yield pathway (Reaction R3a), forming sulfate and methanol and a lower yield pathway (Reaction R3b), forming methyl bisulfite.

$$
\begin{aligned}
& \mathrm{HOSO}_{2}^{-}+\mathrm{CH}_{3} \mathrm{OOH} \rightarrow \mathrm{SO}_{4}^{2-}+\mathrm{H}^{+}+\mathrm{CH}_{3} \mathrm{OH} \\
& \mathrm{HOSO}_{2}^{-}+\mathrm{CH}_{3} \mathrm{OOH} \rightarrow \mathrm{CH}_{3} \mathrm{OSO}_{3}^{-}+\mathrm{H}_{2} \mathrm{O}
\end{aligned}
$$

Lind et al.'s (1987) results for $\mathrm{CH}_{3} \mathrm{OOH}$ and $\mathrm{CH}_{3}(\mathrm{O}) \mathrm{OOH}$ are consistent with a fast initial equilibrium, like Reaction (R1), followed by rearrangement to the products. In addition, Lind et al. (1987) stated that at $\mathrm{pH}$ values above 4.8 the $\mathrm{CH}_{3}(\mathrm{O}) \mathrm{OOH}$ reaction had another mechanism, but the authors did not elaborate, only stated that the mechanism was first-order in both reactants. Reactions (R3a) and (R4) are effectively oxygen atom transfer reactions, analogous to the net (R1) and (R2) Reactions of $\mathrm{H}_{2} \mathrm{O}_{2}$. Reaction (R3b) forms an organosulfate as the stable reaction product (Lind et al., 1987). In our discussion of ISOPOOH reaction pathways we focus on the atmospherically more important 1,2-ISOPOOH. Based on the product distribution we propose a non-fragmentation pathway for 1,2-ISOPOOH forming $1,2-\mathrm{ISOPOH}(22 \%$ molar yield at $\mathrm{pH}=5.5)$ and two fragmentation pathways producing MVK $(30 \%$ molar yield at $\mathrm{pH}=5.5)$ together with formaldehyde/HMS ( $>30 \%$ molar yield at $\mathrm{pH}=5.5)$ and acetic acid $(5 \%$ molar yield at $\mathrm{pH}=5.5$ ) with other small species such as CO. These pathways, accounting for $57 \%$ of 1,2-ISOPOOH reaction at $\mathrm{pH}=5.5$, will be discussed below.

\subsubsection{Non-fragmentation pathway}

Analogous to Reaction (R1), we also consider an initial fast equilibrium of ISOPOOH with $\mathrm{SO}_{2}$,aq. However, because of the lower symmetry than $\mathrm{H}_{2} \mathrm{O}_{2}$, there are two possibilities, depending on which peroxy $\mathrm{O}$ is involved in the nucleophilic attack on sulfur.

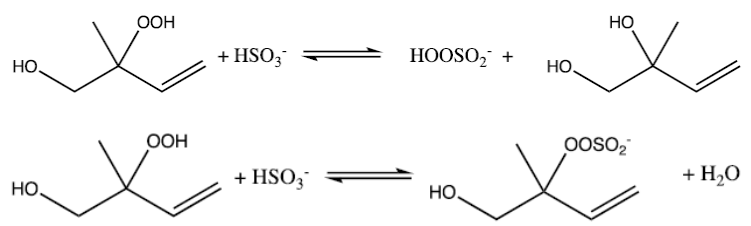

Peroxysulfite from Reaction (R5a) will rearrange to sulfate following Reaction (R2). The organo-peroxysulfite from Reaction (R5b) could potentially rearrange to form an organosulfate (Reaction R6a) which is known to rapidly hydrolyze, forming sulfate and ISOPOH (Darer et al., 2011; $\mathrm{Hu}$ et al., 2011). This rapid hydrolysis of tertiary sulfate likely also applies to the organo-peroxysulfite. The hydrolysis product (Reaction R6b) is again ISOPOH and peroxysulfite, which will rearrange to sulfate following Reaction (R2).

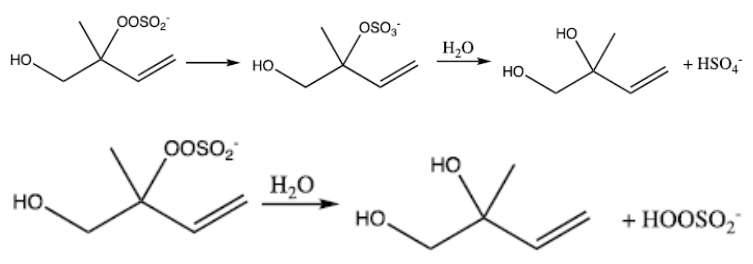

(R6a)

The net outcome of all pathways is effectively an oxygen atom transfer from 1,2-ISOPOOH to sulfite to form sulfate and 1,2-ISOPOH. This net mechanism is consistent with the 
(a)

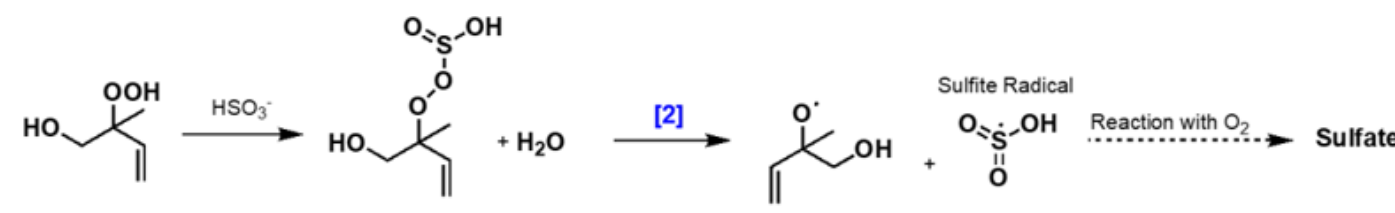

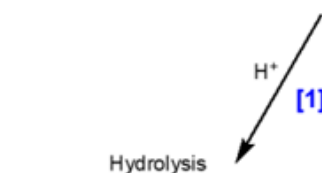

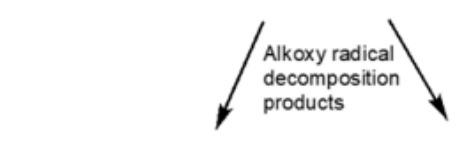<smiles>C=CC(O)(CO)CO</smiles><smiles>C=CC(C)=O</smiles>

$30 \%^{\mathrm{MVK}}$

Formaldehyde

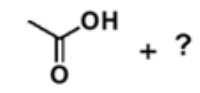

$22 \%_{1,2-\mathrm{ISOPOH}}$

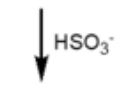<smiles>C[SH](O)OO</smiles><smiles>O=S(=O)(O)O[Na]</smiles>

$\downarrow$

$30 \%$ HMS

(b)

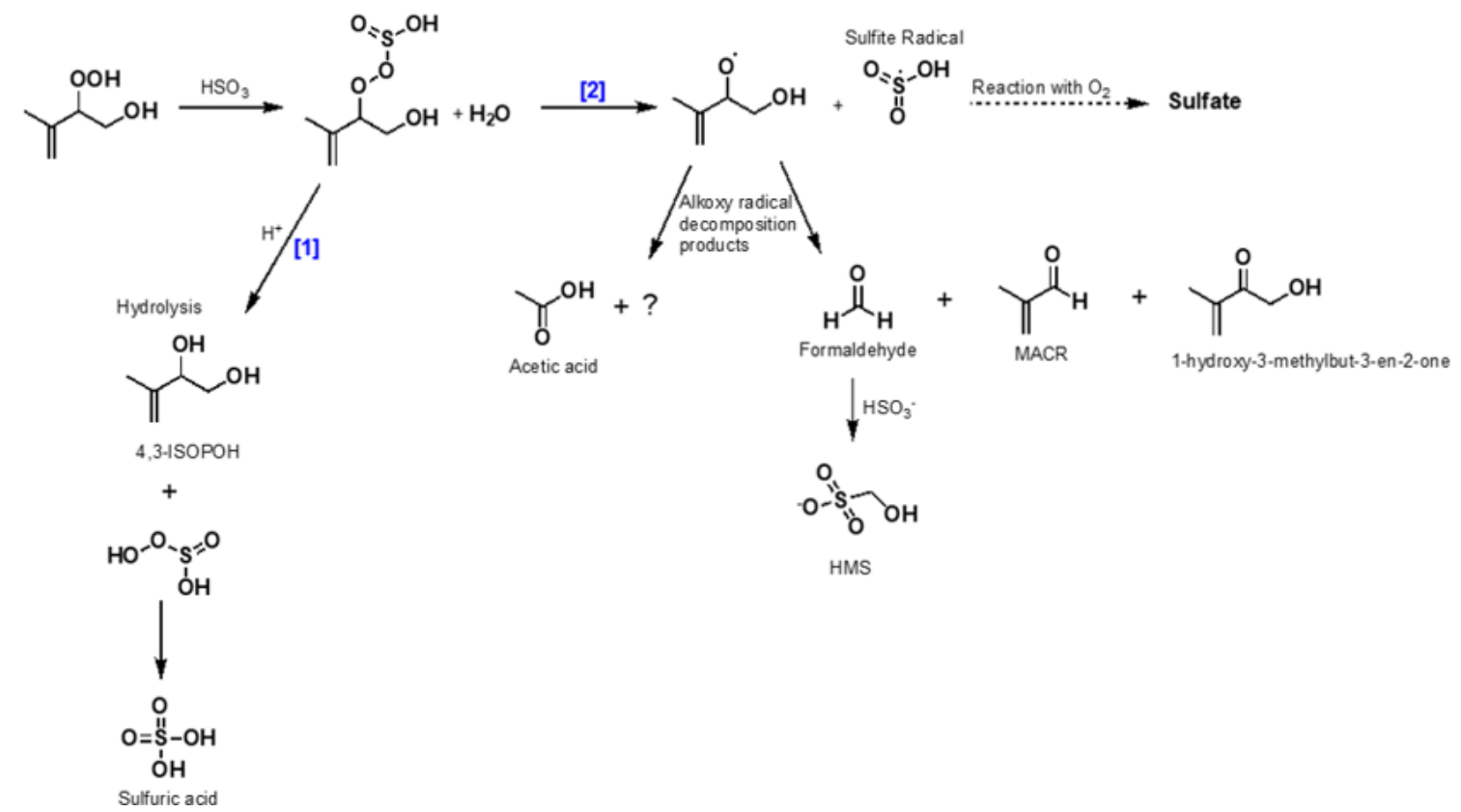

Figure 3. Proposed chemical mechanisms of the oxidation of $\mathrm{SO}_{2}$ aq by (a) $1,2-\mathrm{ISOPOOH}$ with carbon yields of identified products at $\mathrm{pH}=5.5$ (Table 2) presented in purple and (b) 4,3-ISOPOOH. There are two competing mechanisms: after ISOPOOH reacts with $\mathrm{SO}_{2 \text {,aq, }}$, displacing water, a hydrolysis reaction [1] or an $\mathrm{O}-\mathrm{O}$ bond breakage [2] is taking place. In mechanism [1], the product hydrolysis results in the same intermediate that the reaction of $\mathrm{SO}_{2}$,aq with $\mathrm{H}_{2} \mathrm{O}_{2}$ is forming, and either a formation of a diol or an epoxide is being generated (Fig. S2). In mechanism [2], an alkoxy radical and sulfite radical are formed leading to the production of MVK, MACR, HCHO and other products. Considering the reaction of $\mathrm{SO}_{2, \text { aq }}$ with 1,2-ISOPOOH (a), the sum of the products' carbon yields is $57 \%$ and the remaining $43 \%$ is attributed to hydrated formaldehyde, repartition of MVK to the gas phase, and possible formation of CO or other small molecules that have repartitioned to the gas phase, as discussed in Sect. 3.2.2. 
NMR spectra and IC analysis, which show clear evidence for ISOPOH and sulfate production. This effective reaction path is shown in the left-hand side of Fig. 3a[1]. This pathway accounts for $22 \%$ of 1,2-ISOPOOH reaction at $\mathrm{pH}=5.5$.

\subsubsection{Fragmentation pathways}

1,2-ISOPOH yield is only about two-thirds of the yield of MVK at all $\mathrm{pH}$ values, which is strong evidence that an additional pathway, likely not present for $\mathrm{CH}_{3} \mathrm{OOH}$, exists. MVK and formaldehyde, either as its hydrate or as the adduct with the excess $\mathrm{SO}_{2, \mathrm{aq}}$, are in fact the highest yield products. These products have to involve breaking of the carbon backbone, which strongly suggests a radical mechanism. The products are identical to those resulting from oxidation of isoprene by $\mathrm{OH}$ under high-NO conditions, which involves an alkoxy radical (1,2-ISOPO, Fig. 3). In addition, the products are identical to those observed for gas-phase ISOPOOH reacting on metal surfaces (Rivera-Rios et al., 2014). For the latter process, Rivera-Rios et al. (2014) proposed cleavage of the 1,2-ISOPOOH peroxy bond producing 1,2-ISOPO, which rapidly forms MVK and formaldehyde. The high sulfate yield at all $\mathrm{pH}$ values implies that both the ISOPOH and the fragmentation channel have to produce sulfate. In combination with the previous results mentioned above, we propose that the second pathway involves cleavage of the peroxy bond of the organo-peroxysulfite resulting in 1,2ISOPO, which rapidly forms MVK/formaldehyde, and a sulfite radical. The sulfite radical rapidly reacts with $\mathrm{O}_{2}$ producing a peroxysulfate radical, which can undergo further reaction, e.g., with $\mathrm{SO}_{2}$,aq or organic molecules to form sulfate and oxidized organics (Neta and Huie, 1985; Yang et al., 2015). The subsequent (secondary) reaction of HCHO with $\mathrm{SO}_{2 \text {,aq }}$ explains the formation of HMS, and thus the pathway forms MVK, $\mathrm{HCHO}$ and the sulfite radical as first-generation products with the sulfite radical likely forming sulfate subsequently (Fig. 3) (Dovrou et al., 2019a; Munger et al., 1984, 1986). This pathway accounts for $30 \%$ of $1,2-$ ISOPOOH reaction at $\mathrm{pH}=5.5$.

The observation of acetic acid also requires a fragmentation of the backbone. This pathway likely involves formation of additional formaldehyde and $\mathrm{CO}$, which are both not quantifiable in our experiments. For this reason, this is the most uncertain pathway, although it is clear that it accounts for $5 \%$ of 1,2 -ISOPOOH reaction at $\mathrm{pH}=5.5$, which makes the sum of the non-fragmentation and the two fragmentation pathways $57 \%$ at $\mathrm{pH}=5.5$ (Rivera-Rios et al., 2014; Paulot et al., 2009b).

There likely are three contributors to the carbon yield of less than $100 \%$. Hydrated formaldehyde could not be quantified due to interference with $\mathrm{D}_{2} \mathrm{O}$ although this likely is already accounted for in the MVK and acetic acid pathways. However, MVK could also repartition to the gas phase, as discussed in Sect. 4; thus, its aqueous contribution might be underestimated. It is likely that formation of $\mathrm{CO}$ or other small molecules that potentially partition to the gas phase are not detected by NMR. Lastly, it is also possible that numerous small-yield products are formed that are below the NMR detection limit.

\section{3 pH dependence}

The sulfate yield increases while the observed carbon decreases with decreasing $\mathrm{pH}$, and the ratio of ISOPOH to MVK is $\mathrm{pH}$ independent. Moreover, at lower $\mathrm{pH}$, ISOPOH and MVK molar yields are reduced by no more than $10 \%$, and the acetic acid path is greatly reduced. We propose two explanations for the fact that the observed carbon balance decreases with decreasing $\mathrm{pH}$. Kok et al. (1986) showed that the formation of HMS is a factor of 10 slower at $\mathrm{pH}=4$ than $\mathrm{pH}=5$, which could explain that at $\mathrm{pH} \leq 4.5$ the sulfate yield observed in the oxidation of $\mathrm{SO}_{2}$ aq with ISOPOOH is $100 \%$, indicating that $\mathrm{SO}_{2}$,aq is oxidized faster to sulfate than when reacting with formaldehyde to form HMS, while at $\mathrm{pH}=5.5$ the sulfate yield is lower. Thus, the decreased HMS yield is attributed to slow HMS formation so that more formaldehyde stays in the hydrated form which could not be quantified. Second, at lower $\mathrm{pH}$ acetic acid may partition to the gas phase, and thus it cannot be observed. The results do not provide a clear explanation for the lower sulfate yield at $\mathrm{pH}=5.5$. The non-fragmentation (ISOPOH) pathway, which is more important at $\mathrm{pH}=5.5$, cannot explain this as it should have a $100 \%$ sulfate yield. Thus, the cause has to result from one of the fragmentation pathways. It is possible that at higher $\mathrm{pH}$ the sulfite radical has a lower yield of forming sulfate; however, studying this goes beyond the scope of this work.

In addition, $\mathrm{S}(\mathrm{IV})$ speciation might affect the sulfate yield at high $\mathrm{pH}$. While the dominant form of $\mathrm{SO}_{2 \text {,aq }}$ in our experiments is bisulfite, at the highest $\mathrm{pH}$ value of our experiments, $\mathrm{pH}=5.5$, sulfite is likely formed and could potentially react with ISOPOOH (Fig. S1). The ratio of bisulfite to sulfite at $\mathrm{pH}=5.5$ is approximately 60 . However, if the rate constant of ISOPOOH with sulfite is orders of magnitude faster than the reaction of ISOPOOH with bisulfite, and the reaction mechanism is different for sulfite than bisulfite, this could contribute to changes in product distributions. Our experiments do not allow unambiguous and quantitative analysis of this aspect. Performing experiments at higher $\mathrm{pH}$, exceeding the cloud-relevant $\mathrm{pH}$, to shift the equilibrium to sulfite has the significant complication that formaldehyde will react rapidly with it to form HMS.

In summary, we observe clear evidence for a nonfragmentation pathway that likely is similar to the mechanism of $\mathrm{H}_{2} \mathrm{O}_{2}$ and $\mathrm{CH}_{3} \mathrm{OOH}$. A difference to $\mathrm{CH}_{3} \mathrm{OOH}$ is that in contrast to methyl bisulfate the organo-sulfates from ISOPOOH hydrolyze easily, especially the tertiary one from 1,2-ISOPOOH. The non-fragmentation pathway effectively corresponds to an oxygen atom transfer, and in contrast to $\mathrm{H}_{2} \mathrm{O}_{2}$ and $\mathrm{CH}_{3} \mathrm{OOH}$ this is not the major pathway. We ob- 
serve fragmentation pathways that we hypothesize involve cleavage of the peroxy bond based on previous work on ISOPOOH. Such a pathway was not observed for $\mathrm{CH}_{3} \mathrm{OOH}$ as the product of this channel would be neither methanol nor methyl bisulfate. There are at least two fragmentation pathways, with the major observed one producing MVK and $\mathrm{HCHO}$, which subsequently forms HMS, and a minor one forming acetic acid and probably small molecules including CO. It is likely that additional smaller molecules that partition to the gas phase are formed as well as other molecules at low concentration that cannot be detected via NMR, which could include organo-sulfur compounds from the reaction of the sulfite radical with organics.

\section{Atmospheric implications}

In the atmosphere, MVK and MACR will partition to the gas phase as they have high vapour pressures of 11 and $16 \mathrm{kPa}$ and low Henry's law constants of 41 and $6.5 \mathrm{Matm}^{-1}$, respectively (Iraci et al., 1999). The diffusion time of MVK in a cloud droplet is less than $25 \mathrm{~s}$. The rate of the reaction of MVK with $\mathrm{SO}_{2 \text {,aq }}$ was estimated using NMR analysis, from which we estimate a lower limit for the rate constant of $k \geq 10^{4} \mathrm{M}^{-1} \mathrm{~s}^{-1}$. However, considering the diffusion time, $\mathrm{SO}_{2 \text {,aq }}$ and expected MVK concentrations, the formation of the organosulfur compound by reaction of $\mathrm{MVK}$ with $\mathrm{SO}_{2 \text {,aq }}$ is unlikely in the atmosphere.

The annual production of the products formed via the reaction of ISOPOOH with $\mathrm{SO}_{2, \text { aq }}$ in the atmosphere was calculated using the estimated ISOPOOH amount participating in this reaction from GEOS-Chem (Bey et al., 2001; Park et al., 2004; Alexander et al., 2012; Dovrou et al., 2019b). The results from the simulations performed in the work of Dovrou et al. (2019b) were re-analysed with respect to the amount of ISOPOOH reacting in each pathway. Dovrou et al. (2019b) did not consider the organic products of the $\mathrm{ISOPOOH}+\mathrm{SO}_{2}$, aq reaction as they focused on an estimate of the globally and regionally produced sulfate (see Dovrou et al., 2019b, for all details on model configurations). This work focused on the organic reaction products, primarily to provide the first insight into this for multifunctional organic hydroperoxides, and to evaluate whether in addition to the clear regional importance for sulfate, the reactions are important for the organic carbon budget. To be specific, the amount of ISOPOOH reacting in each pathway was calculated from the simulations and was adjusted for each organic product using the product yields. The results were scaled by the relative molecular weights in order to calculate the total production of the compounds of interest.

Globally, it is estimated that, under current conditions, 4.2 $\mathrm{Tg} \mathrm{yr}^{-1}$ of gas-phase 1,2-ISOPOOH reacts with $\mathrm{SO}_{2, \text { aq }}$, representing $3.2 \%$ of the global loss of the ISOPOOH isomer and $1.7 \%$ of the global production of sulfate (Dovrou et al., 2019b). The 1,2-ISOPOOH pathway contributes to the production of $0.40-0.53,0.02-0.06,0.28-0.36,0.95-1.31$ and $1.40-1.52 \mathrm{Tg} \mathrm{yr}^{-1}$ of MVK, acetic acid, HCHO, HMS and 1,2-ISOPOH, respectively (ranges are for the differences in yields across the experimental $\mathrm{pH}$ range). The production of MVK from these ISOPOOH+ $\mathrm{SO}_{2}$, aq oxidation pathways is equivalent to $0.5 \%$ of the total global production under present conditions. Under pre-industrial conditions, the total atmospheric burden of $\mathrm{SO}_{2}$ decreases; thus, the amount of ISOPOOH reacting with $\mathrm{SO}_{2 \text {,aq }}$ decreases somewhat: $2.4 \mathrm{Tgyr}^{-1}$ of gas-phase $1,2-\mathrm{ISOPOOH}$ reacts with $\mathrm{SO}_{2, \text { aq }}$, representing $1.6 \%$ of the global respective losses of the isomer and $1.0 \%$ of the global production of sulfate. The reaction of 1,2-ISOPOOH+ $\mathrm{SO}_{2}$, aq results in 0.23 $0.30,0.01-0.04,0.16-0.21,0.55-0.76$ and $0.80-0.88 \mathrm{Tg} \mathrm{yr}^{-1}$ of MVK, acetic acid, HCHO, HMS and 1,2-ISOPOH, respectively. The production of MVK from these ISOPOOH+ $\mathrm{SO}_{2 \text {,aq }}$ oxidation pathways is equivalent to $3.7 \%$ of the total global production under pre-industrial conditions. These results show that the importance of these pathways lies in the production of sulfate on regional scales, especially for isoprene-dominated regions, rather than the formation of the organic reaction products. The conversion of bisulfite to sulfate via the 1,2-ISOPOOH pathway can contribute up to $\sim 50 \%$ of total sulfate production in pristine regions such as the Amazon, and $\sim 3 \%$ in more polluted regions such as the southeastern United States under current atmospheric conditions (Dovrou et al., 2019b). The southeastern United States is an area of interest as $\mathrm{NO}_{x}$ levels are decreasing, creating an atmosphere where hydroperoxide formation can be favoured, which may increase their contribution to sulfate formation; in a simulation without anthropogenic emissions, the contribution of ISOPOOH to sulfate formation increases from $\sim 3 \%$ to $\sim 20 \%$ (Dovrou et al., 2019b).

\section{Conclusions}

This work is primarily useful as a foundation for the mechanistic understanding of the reactivity of multifunctional organic hydroperoxides with $\mathrm{SO}_{2}$,aq, for which there is no previous data in the literature. The results show that multifunctional organic hydroperoxides have a significantly more complex behaviour with channels analogous to $\mathrm{H}_{2} \mathrm{O}_{2}$ and $\mathrm{CH}_{3} \mathrm{OOH}$ but also fragmentation channels. Dovrou et al. (2019b) demonstrated the importance of these pathways in the production of sulfate under isoprene-dominated regions compared to the formation of the organic reaction products. Although the reactions do not play an important role for the organic carbon budget, our work advances understanding of the atmospheric chemistry of multifunctional organic hydroperoxides and adds new pathways to the isoprene oxidation mechanism. Furthermore, the results can help clarify the composition of cloud droplet residual aerosols. 
Data availability. The data used in this work are available upon request. Please email Eleni Dovrou (dovrouel@gmail.com).

Supplement. The supplement related to this article is available online at: https://doi.org/10.5194/acp-21-8999-2021-supplement.

Author contributions. ED conducted the ion chromatography experiments and ED and JCRR conducted the NMR experiments. ED, KHB and FNK analysed the data. JCRR synthesized the two ISOPOOH isomers. JLC and JDS synthesized the 1,2-ISOPOH to provide the ${ }^{1} \mathrm{H}-\mathrm{NMR}$ standard, and JLC provided the 2-methyl-2vinyloxirane and acetic acid ${ }^{1} \mathrm{H}-\mathrm{NMR}$ standards. ED prepared the paper with contributions from KHB, JCRR, JLC, JDS and FNK.

Competing interests. The authors declare that they have no conflict of interest.

Acknowledgements. This work was supported by the Harvard Global Institute. Eleni Dovrou is grateful for the Onassis Foundation scholarship for Hellenes.

Financial support. This research has been supported by the Harvard Global Institute.

The article processing charges for this open-access publication were covered by the Max Planck Society.

Review statement. This paper was edited by Ryan Sullivan and reviewed by Becky Alexander and one anonymous referee.

\section{References}

Alexander, B., Allman, D. J., Amos, H. M., Fairlie, T. D., Dachs, J., Hegg, D. A., and Sletten, R. S.: Isotopic constraints on the formation pathways of sulfate aerosol in the marine boundary layer of the subtropical northeast Atlantic Ocean, J. Geophys. Res., 117, 1-17, https://doi.org/10.1029/2011JD016773, 2012.

Bates, K. H., Crounse, J. D., St. Clair, J. M., Bennett, N. B., Nguyen, T. B., Seinfeld, J. H., Stoltz, B. M., and Wennberg, P. O.: Gas phase production and loss of isoprene epoxydiols, J. Phys. Chem. A, 118, 1237-1246, https://doi.org/10.1021/jp4107958, 2014.

Bey, I., Jacob, J., Yantosca, R. M., Logan, A., Field, B. D., Fiore, A. M., Li, Q., Liu, H. Y., Mickley, J., and Schultz, M. G.: Global modeling of tropospheric chemistry with assimilated meteorology: Model description and evaluation, J. Geophys. Res.-Atmos., 106, 73-95, https://doi.org/10.1029/2001JD000807, 2001.

Darer, A. I., Cole-Filipiak, N. C., O'Connor, A. E., and Elrod, M. J.: Formation and stability of atmospherically relevant isoprenederived organosulfates and organonitrates, Environ. Sci. Technol., 45, 1895-1902, https://doi.org/10.1021/es103797z, 2011.
Dovrou, E., Lim, C. Y., Canagaratna, M. R., Kroll, J. H., Worsnop, D. R., and Keutsch, F. N.: Measurement techniques for identifying and quantifying hydroxymethanesulfonate (HMS) in an aqueous matrix and particulate matter using aerosol mass spectrometry and ion chromatography, Atmos. Meas. Tech., 12, 5303-5315, https://doi.org/10.5194/amt-12-5303-2019, 2019a.

Dovrou, E., Rivera-Rios, J. C., Bates, K. H., and Keutsch, F. N.: Sulfate Formation via Cloud Processing from Isoprene Hydroxyl Hydroperoxides (ISOPOOH), Environ. Sci. Technol., 53, 1247612484, https://doi.org/10.1021/acs.est.9b04645, 2019b.

Guenther, A., Karl, T., Harley, P., Wiedinmyer, C., Palmer, P. I., and Geron, C.: Estimates of global terrestrial isoprene emissions using MEGAN (Model of Emissions of Gases and Aerosols from Nature), Atmos. Chem. Phys., 6, 3181-3210, https://doi.org/10.5194/acp-6-3181-2006, 2006.

Guenther, A. B., Jiang, X., Heald, C. L., Sakulyanontvittaya, T., Duhl, T., Emmons, L. K., and Wang, X.: The Model of Emissions of Gases and Aerosols from Nature version 2.1 (MEGAN2.1): an extended and updated framework for modeling biogenic emissions, Geosci. Model Dev., 5, 1471-1492, https://doi.org/10.5194/gmd-5-1471-2012, 2012.

Hoffmann, M. R. and Edwards, J. O.: Kinetics of the oxidation of sulfite by hydrogen peroxide in acidic solution, J. Phys. Chem., 79, 2096-2098, https://doi.org/10.1021/j100587a005, 1975.

Hu, K. S., Darer, A. I., and Elrod, M. J.: Thermodynamics and kinetics of the hydrolysis of atmospherically relevant organonitrates and organosulfates, Atmos. Chem. Phys., 11, 8307-8320, https://doi.org/10.5194/acp-11-8307-2011, 2011.

Iraci, L. T., Baker, B. M., Tyndall, G. S., and Orlando, J. J.: Measurements of the Henry's law coefficients of 2-methyl-3-buten-2ol, methacrolein, and methylvinyl ketone, J. Atmos. Chem., 33, 321-330, https://doi.org/10.1023/A:1006169029230, 1999.

Kok, G. L., Gitlin, S. N., and Lazrus, A. L.: Kinetics of the Formation and Decomposition of Hydroxymethanesulfonate, J. Geophys. Res., 91, 2801-2804, https://doi.org/10.1029/JD091iD02p02801, 1986.

Krechmer, J. E., Coggon, M. M., Massoli, P., Nguyen, T. B., Crounse, J. D., Hu, W., Day, D. A., Tyndall, G. S., Henze, D. K., Rivera-Rios, J. C., Nowak, J. B., Kimmel, J. R., Mauldin, R. L., Stark, H., Jayne, J. T., Sipilä, M., Junninen, H., St. Clair, J. M., Zhang, X., Feiner, P. A., Zhang, L., Miller, D. O., Brune, W. H., Keutsch, F. N., Wennberg, P. O., Seinfeld, J. H., Worsnop, D. R., Jimenez, J. L., and Canagaratna, M. R.: Formation of Low Volatility Organic Compounds and Secondary Organic Aerosol from Isoprene Hydroxyhydroperoxide Low-NO Oxidation, Environ. Sci. Technol., 49, 10330-10339, https://doi.org/10.1021/acs.est.5b02031, 2015.

Lin, Y. H., Zhang, Z., Docherty, K. S., Zhang, H., Budisulistiorini, S. H., Rubitschun, C. L., Shaw, S. L., Knipping, E. M., Edgerton, E. S., Kleindienst, T. E., Gold, A., and Surratt, J. D.: Isoprene epoxydiols as precursors to secondary organic aerosol formation: Acid-catalyzed reactive uptake studies with authentic compounds, Environ. Sci. Technol., 46, 250-258, https://doi.org/10.1021/es202554c, 2012.

Lind, J. A., Lazrus, A. L., and Kok, G. L.: Aqueous Phase Oxidation of Sulfur(Iv) By Hydrogen-Peroxide, Methylhydroperoxide, and Peroxyacetic Acid, J. Geophys. Res., 92, 4171-4177, https://doi.org/10.1029/JD092iD04p04171, 1987. 
Liu, Y., Brito, J., Dorris, M. R., Rivera-Rios, J. C., Seco, R., Bates, K. H., Artaxo, P., Duvoisin Jr., S., Keutsch, F. N., Kim, S., Goldstein, A. H., Guenther, A. B., Manzi, A. O., Souza, R. A. F., Springston, S. R., Watson, T. B., McKinney, K. A., and Martin, A. T.: Isoprene photochemistry over the Amazon rainforest, P. Natl. Acad. Sci. USA, 113, 6125-6130, https://doi.org/10.1073/pnas.1524136113, 2016.

McNeill, V. F.: Aqueous organic chemistry in the atmosphere: Sources and chemical processing of organic aerosols, Environ. Sci. Technol., 49, 1237-1244, https://doi.org/10.1021/es5043707, 2015.

Munger, J. W., Jacob, D. J., and Hoffmann, M. R.: The occurrence of bisulfite-aldehyde addition products in fog- and cloudwater, J. Atmos. Chem., 1, 335-350, https://doi.org/10.1007/BF00053799, 1984.

Munger, J. W., Tiller, C., and Hoffmann, M. R.: Identification of hydroxymethanesulfonate in fog water, Science, 231, 247-249, https://doi.org/10.1126/science.231.4735.247, 1986.

Neta, P. and Huie, R. E.: Free-radical chemistry of sulfite, Environ. Health Persp., 64, 209-217, https://doi.org/10.2307/3430011, 1985.

Nguyen, T. B., Coggon, M. M., Bates, K. H., Zhang, X., Schwantes, R. H., Schilling, K. A., Loza, C. L., Flagan, R. C., Wennberg, P. O., and Seinfeld, J. H.: Organic aerosol formation from the reactive uptake of isoprene epoxydiols (IEPOX) onto nonacidified inorganic seeds, Atmos. Chem. Phys., 14, 3497-3510, https://doi.org/10.5194/acp-14-3497-2014, 2014.

Park, R. J., Jacob, D. J., Field, B. D., and Yantosca, R. M.: Natural and transboundary pollution influences on sulfate-nitrate- ammonium aerosols in the United States: Implications for policy, J. Geophys. Res., 109, 1-17, https://doi.org/10.1029/2003JD004473, 2004.

Paulot, F., Crounse, J. D., Kjaergaard, H. G., Kürten, A., Clair, J. M. S., Seinfeld, J. H., and Wennberg, P. O.: Unexpected Epoxide Formation in the Gas-Phase Photooxidation of Isoprene, Science, 325, 730-734, 2009a.

Paulot, F., Crounse, J. D., Kjaergaard, H. G., Kroll, J. H., Seinfeld, J. H., and Wennberg, P. O.: Isoprene photooxidation: new insights into the production of acids and organic nitrates, Atmos. Chem. Phys., 9, 1479-1501, https://doi.org/10.5194/acp-9-14792009, 2009b.

Rivera-Rios, J. C.: Atmospheric Chemistry of Isoprene Hydroxyhydroperoxides, $\mathrm{PhD}$ dissertation, Harvard University, Cambridge MA, May 2018.

Rivera-Rios, J. C., Nguyen, T. B., Crounse, J. D., Jud, W., St. Clair, J. M., Mikoviny, T., Gilman, J. B., Lerner, B. M., Kaiser, J. B., De Gouw, J., Wisthaler, A., Hansel, A., Wennberg, P. O., Seinfeld, J. H., and Keutsch, F. N.: Conversion of hydroperoxides to carbonyls in field and laboratory instrumentation: Observational bias in diagnosing pristine versus anthropogenically controlled atmospheric chemistry, Geophys. Res. Lett., 41, 86458651, https://doi.org/10.1002/2014GL061919, 2014.
St. Clair, J. M., Rivera-Rios, J. C., Crounse, J. D., Praske, E., Kim, M. J., Wolfe, G. M., Keutsch, F. N., Wennberg, P. O., and Hanisco, T. F.: Investigation of a potential HCHO measurement artifact from ISOPOOH, Atmos. Meas. Tech., 9, 4561-4568, https://doi.org/10.5194/amt-9-4561-2016, 2016.

Surratt, J. D., Chan, A. W. H., Eddingsaas, N. C., Chan, M. N., Loza, C. L., Kwan, A. J., Hersey, S. P., Flagan, R. C., Wennberg, P. O., and Seinfeld, J. H.: Reactive intermediates revealed in secondary organic aerosol formation from isoprene, P. Natl. Acad. Sci. USA, 107, 6640-6645, https://doi.org/10.1073/pnas.0911114107, 2010.

Wennberg, P. O., Bates, K. H., Crounse, J. D., Dodson, L. G., Mcvay, R. C., Mertens, L. A., Nguyen, T. B., Praske, E., Schwantes, R. H., Smarte, M. D., Clair, J. M. S., Teng, A. P., Zhang, X., and Seinfeld, J. H.: Gas-Phase Reactions of Isoprene and Its Major Oxidation Products, Chem. Rev., 118, 3337-3390, https://doi.org/10.1021/acs.chemrev.7b00439, 2018.

Worton, D. R., Surratt, J. D., Lafranchi, B. W., Chan, A. W. H., Zhao, Y., Weber, R. J., Park, J. H., Gilman, J. B., De Gouw, J., Park, C., Schade, G., Beaver, M., Clair, J. M. S., Crounse, J., Wennberg, P., Wolfe, G. M., Harrold, S., Thornton, J. A., Farmer, D. K., Docherty, K. S., Cubison, M. J., Jimenez, J. L., Frossard, A. A., Russell, L. M., Kristensen, K., Glasius, M., Mao, J., Ren, X., Brune, W., Browne, E. C., Pusede, S. E., Cohen, R. C., Seinfeld, J. H., and Goldstein, A. H.: Observational insights into aerosol formation from isoprene, Environ. Sci. Technol., 47, 11403-11413, https://doi.org/10.1021/es4011064, 2013.

Yang, Y., Jiang, J., Lu, X., Ma, J., and Liu, Y.: Production of Sulfate Radical and Hydroxyl Radical by Reaction of Ozone with Peroxymonosulfate: A Novel Advanced Oxidation Process, Environ. Sci. Technol., 49, 73307339, https://doi.org/10.1021/es506362e, 2015.

Zhang, Y., Chen, Y., Lambe, A. T., Olson, N. E., Lei, Z., Craig, R. L., Zhang, Z., Gold, A., Onasch, T. B., Jayne, J. T., Worsnop, D. R., Gaston, C. J., Thornton, J. A., Vizuete, W., Ault, A. P., and Surratt, J. D.: Effect of the Aerosol-Phase State on Secondary Organic Aerosol Formation from the Reactive Uptake of IsopreneDerived Epoxydiols (IEPOX), Environ. Sci. Tech. Let., 5, 167174, https://doi.org/10.1021/acs.estlett.8b00044, 2018.

Zhang, Z., Lin, Y. H., Zhang, H., Surratt, J. D., Ball, L. M., and Gold, A.: Technical Note: Synthesis of isoprene atmospheric oxidation products: Isomeric epoxydiols and the rearrangement products cis- and trans-3-methyl-3,4dihydroxytetrahydrofuran, Atmos. Chem. Phys., 12, 8529-8535, https://doi.org/10.5194/acp-12-8529-2012, 2012. 